\title{
Leporinus elongatus induced spawning using carp pituitary extract or mammalian GnRH analogue combined with dopamine receptor antagonists
}

\author{
Thiago Scremin Boscolo Pereira ${ }^{1,2}$, Camila Nomura Pereira Boscolo ${ }^{1}$, Renata Guimarães Moreira ${ }^{3}$, \\ Sergio Ricardo Batlouni ${ }^{4,5}$ \\ ${ }^{1}$ University Center of Rio Preto (UNIRP), Sao Paulo, Brazil \\ ${ }^{2}$ Medical School FACERES, Morphofunctional laboratory, Sao Jose do Rio Preto, SP, Brazil \\ ${ }^{3}$ University of Sao Paulo (USP), Institute of Biosciences, Sao Paulo, Brazil. \\ ${ }^{4}$ Sao Paulo State University (UNESP), Aquaculture Center (CAUNESP), Sao Paulo, Brazil.
}

\begin{abstract}
Several studies have been developed to support the replacement of the crude carp pituitary extract (CPE) by synthetic products for induced reproduction of South American rheophilic species. However, results have been quite heterogeneous and there is no consensus or a routine use of synthetic products in these species. Thus, the aim of this study was to evaluate the ovulatory process in $L$. elongatus using different protocols of hormonal induction. Thus, fifteen wild mature females maintained at the Experimental Fish Station, Salto Grande, SP, Brazil were submitted to three different hormonal treatments: CPE (fractioned dose: 0.5 and $5.0 \mathrm{mg} \mathrm{kg}^{-1}$ ); mGnRHa (single dose: $3.5 \mu \mathrm{g} \mathrm{kg}^{-1}$ ) and mGnRHa (single dose: $5.0 \mu \mathrm{g} \mathrm{kg}^{-1}$ ). The spawning rate and absolute fecundity were similar among the treatments, but fertility rates were higher for CPE treatment $(23.60 \pm 9.40)$ then for mGnRHa treatments (close to or zero zero). Although females ovulated in all treatments, none of them provided viable embryos, showing hatching rates close to zero or zero. Both mGnRHa treatments were more potent for inducing the ovulatory process then CPE treatment, which was evidenced by the fact that the formers showed higher volume density of postovulatory follicles (POF). Accordingly, $\mathrm{E}_{2}$ and $17 \alpha$-OHP plasma levels were higher for the $\mathrm{mGnRHa}$ treated females compared to the CPE one at the time of ovulation. In this study we confirmed previous scientific evidence that, regardless of whether promoting ovulation, the use of conventional $\mathrm{CPE}$ and GnRH doses are not appropriate for some South American migratory species, due to the nonattainment of viable embryos. Moreover, we have brought new information about the relationship between reproductive performance and gonadal steroids concentrations using different hormonal therapies, contributing to understand the reasons for Leporinus elongatus embryo loss in induced spawning.
\end{abstract}

Keywords: final maturation, gonadal steroids, hormonal treatment, ovulation, spawning performance.

\section{Introduction}

Leporinus elongatus is a medium-sized, total spawner rheophilic fish, commercially relevant and known to be a good model for studies concerning the reproductive biology of rheophilic species (Duke Energy International-Geração Paranapanema S/A., 2003). Moreover, this species was one of the ten most produced fish in Brazil in 2014 (IBGE, 2014), mainly due to its high quality meat (Duke Energy InternationalGeração Paranapanema S/A., 2003) and acceptance for commercial, subsistence, and sport fishing purposes (Petrere et al., 2002; Giamas and Vermulm-Jr, 2004). It is similar to other tropical rheophilic fish which perform a reproductive migration in order to have a total spawning in their native habitat. However, when kept in captivity, even though they reach advanced stages of gonadal development, the final maturation and ovulation does not occur (Godinho, 2007; Makrakis et al., 2007; Brito and Carvalho, 2013). Therefore, this rheophilic species needs to be hormonally induced for providing fingerlings under captivity conditions (Sato et al., 2000; Streit-Jr et al., 2008).

In this concern, the use of Gonadotrophin releasing hormones analogues ( $\mathrm{GnRHa}$ ) has grown rapidly due to its numerous advantages, but mainly because they are not species-specific molecules and present high structural similarities among fish. Moreover, due to their synthetic nature, they pose no risk of transmitting diseases, such as carp pituitary extracts (CPE) do, and since they act at higher levels of the hypothalamic-pituitary gonad axis, they stimulate the release of $\mathrm{LH}$ and $\mathrm{FSH}$, as well as other pituitary hormones, which may serve important reproductive functions (review in Mylonas et al., 2010). However, although the efficiencies of the use of synthetic products in some South American rheophilic species (Ittze's et al., 2015; Viveiros et al., 2015) have already been shown - such as obtaining ovulation and viable embryos - and even if they sometimes have a higher potential for inducing ovulation compared to that of CPE (Pereira et al., 2017), the use of mGnRH in these species is frequently associated with ovulation failure (Carneiro and Mikos, 2008) and / or failure in obtaining viable embryos (Acuña and Rangel 2009; Paulino et al., 2011; Pereira et al., 2017).

Therefore, the most commonly used technique for obtaining viable embryos from South American rheophilic species is still the hypophysation with the application of CPE (0.5 and $5.0 \mathrm{mg} \mathrm{kg}$ ) (Caneppele et al., 2015; De Souza et al., 2015; Ittzés et al., 2015; Viveiros et al., 2015; Schorer et al., 2016; Pereira et al., 
2017). Nevertheless, the main problem related to the use of CPE is a constant uncertainty and unpredictability of a successful ovulation (Criscuolo-Urbinati et al., 2012; Hainfellner et al., 2012a; 2012b; Pereira et al., 2017). In the specific case of $L$. elongatus, the low potential for inducing ovulation, the heterogeneous results concerning fertility rates and the number of oocytes that are retained in the post-spawning ovaries using CPE are highlighted by Sato and collaborators (2000). A high proportion of oocytes retained in the ovaries after stripping (week ovulation) also seems to be a constant in treatments using CPE in South American rheophilic species (Sato et al., 2000; Hainfellner et al., 2012a; 2012b; Criscuolo-Urbinati et al., 2012; Pereira et al., 2017). Thus, in this study we aimed at improving $L$. elongatus reproductive performance by using low doses of $\mathrm{mGnRHa}$ and then comparing the evolution of the final maturation and ovulation obtained through this treatment with that obtained through the use of conventional CPE doses.

\section{Materials and methods}

\section{Broodstock maintenance}

Wild males and females (at a sex ratio of 1:1) were maintained at Duke Energy's Experimental Fish Station (22 ${ }^{\circ} 54^{\prime} 23.81$ "S and $50^{\circ} 00$ '05.06" W). The animals were kept in $200 \mathrm{~m}^{2}$ ponds (ca. 0.25 fish $\mathrm{m}^{2}$ ) under average temperature of $27^{\circ} \mathrm{C}$ and natural photoperiod. Fish were manually fed a pelleted balanced commercial diet (moisture content 10.0\%; crude protein $32.0 \%$; ethereal extract $10.0 \%$; fibrous matter $7.0 \%$; ash $10.0 \%$; calcium $1.2 \%$; phosphorus $1.2 \%$ ) corresponding to $3.0 \%$ of total body weight twice a day.

\section{Experimental Protocols}

Fifteen mature females with a mean biomass of (mean \pm SEM) $1.5+0.4 \mathrm{~kg}$ were randomly selected for the induced breeding experiments. At the time of spawning, broodstock were transported to the lab for acclimatization and maintained in $500 \mathrm{~L}$ tanks with constant water circulation. Females were randomly submitted to three different hormonal treatments: 1-) crude carp pituitary extract (CPE) (Fish braz $\left.{ }^{\circledR}\right)$ - two doses $\left(0.5\right.$ and $5.0 \mathrm{mg} \mathrm{kg}^{-1}, 12 \mathrm{~h}$ interval, diluted in 0.5 $\mathrm{mL}$ saline - 0.9\%); 2-) mammalian gonadotropinreleasing hormone analogue (mGnRHa) (conceptal ${ }^{\circledR} /$ Intervet) - single dose (3.5 $\mu \mathrm{g} \mathrm{kg}^{-1}$, diluted in $10 \mathrm{ml}$ sterile buffered diluent, associated with a dopamine inhibitor $\left(10 \mathrm{mg} \mathrm{kg}^{-1}\right.$ metoclopramide, diluted in $0.5 \mathrm{ml}$ saline - 0.9\%) and 3-) mammalian gonadotropinreleasing hormone analogue (mGnRHa) (conceptal ${ }^{\circledR} /$ Intervet) - single dose $\left(5.0 \mu \mathrm{g} \mathrm{kg}^{-1}\right.$, diluted in $10 \mathrm{ml}$ sterile buffered diluent, associated with a dopamine inhibitor (10 mg kg-1 metoclopramide, diluted in $0.5 \mathrm{ml}$ saline - 0.9\%).

\section{Reproductive performance}

The latency period was defined as the time between the first injection and fish ovulation for CPE treatment percentage of spawning females was determined using the following formula: total number of spawned females/total number of induced females x 100 . The total number of oocytes released by each female (absolute fecundity) was estimated according to the method proposed by Pereira et al. (2017). After that, oocytes of each female were fertilized using a pool of semen from males from the same broodstock. To avoid the effects of factors unrelated to the influence of the females during the artificial breeding process, the same pool of semen was used for all treatments. Approximately $0.5 \mathrm{~mL}$ semen was used to fertilize $50 \mathrm{~g}$ of oocytes.

Soon after fertilization, $\sim 50 \mathrm{ml}$ of eggs from each female were distributed into four funnel-shaped plastic incubators with a capacity of $18 \mathrm{~L}$. Then, $18 \mathrm{~g}$ of eggs were placed in each incubator with a constant water flow of $5 \mathrm{~L} / \mathrm{min}^{-1}$. To determine the fertilization rate, 8-12 hours post-fertilization, 100 eggs from each female were randomly sampled and counted, and those which were normally dividing were scored (viable embryos). After 17 post-fertilization, overall hatching rate was determined by counting the number of hatched eggs/number of fertilized eggs X 100 .

All spawned females were euthanized after spawning with an overdose of anesthesia (2 g ethylaminobenzoate: $150 \mathrm{~mL}$ alcohol: $20 \mathrm{~L}$ water) and had their ovaries collected. The gonadosomatic index (GSI) was determined according to Criscuolo-Urbinati et al. (2012) and Pereira et al. (2017) proposed formulae for calculating this index in post-spawning females.

Water parameters were measured throughout the latency period and egg incubation (measured every experimental day at 09:00 h) using a YSI model 55 oximeter and a YSI model 63 multiparameter sonde (Yellow Spring Instruments, Yellow Springs, $\mathrm{OH}$, USA). The experiments were performed under natural photoperiod and average water mean temperature, $\mathrm{pH}$ and dissolved oxygen were respectively $26.5 \pm 1.25^{\circ} \mathrm{C}$, $6.9 \pm 0.4$ and $6.03 \pm 0.54 \mathrm{mg} \mathrm{L}^{-1}$.

\section{Histomorphometric analyses}

For the histological evaluation (volume density), cranial, medial, and tail regions of the ovary tissues were fixed in Bouin solution for routine histological procedures, according to the metodology applied by Pereira et al. (2017)

The volume density was determined using light microscopy and a 320-intersection grid. Three fields from each region of the ovary (anterior, medial, and cranial; total of nine fields) were randomly selected, with a total of 2880 points scored for each animal at magnification X 4. For this analysis, the methodology applied by Pereira et al. (2017), was used with some modifications. Points were classified as one of the 
following: previtellogenic oocyte (PV), cortical alveoli oocyte (CA), immature oocytes with incomplete vitellogenesis and cytoplasm not fully filled by yolk (IV), mature vitellogenic oocytes with cytoplasm filled entirely by yolk and central nucleus (CNV), mature vitellogenic oocytes with cytoplasm filled entirely by yolk and showing germinal vesicle break down (GVBD), and atretic oocyte (AT).

\section{Blood sampling and steroids assays}

Blood was collected at the moment of each hormonal doses and at the time of ovulation. Blood was collected by puncturing the caudal vein with heparinized syringes (Liquemine, Roche, Rio de Janeiro, RJ, Brazil) and needles. Blood was centrifuged at $1300 \mathrm{~g}$ for 10 minutes. The plasma was separated into aliquots and frozen at $-80^{\circ} \mathrm{C}$ for the subsequent $17 \beta$ estradiol $\left(E_{2}\right)$ and $17 \alpha$-hydroxyprogesterone $(17 \alpha-\mathrm{OHP})$ assays. The plasma steroid level was measured through ELISA (Enzyme Linked Immunosorbent Assay) ( $\mathrm{E}_{2}$ and 17 $\alpha$-OHP: Interteck, Virginia, USA). Plasma samples were run in duplicate with an acceptable limit of $\leq 20.0$ for the intra-assay coefficients of variation (Brown et al., 2004). Absorbance measurements were collected using a microplate reader (Molecular Devices, CA, USA).

\section{Statistical analysis}

Data normality was verified using the Cramer- von Mises test. Homoscedasticity was checked through the Fmax test. ANOVA test was used to analyze all parameters of reproductive performance, except for the percentage of spawning, which was analyzed through the Chi - square test $\left(\mathrm{X}^{2}\right)$. The volume density was analyzed by comparing different treatments with a oneway analysis of variance (ANOVA). In order to analyze the gonadal steroids, two-way ANOVA for repeated measures was used. The Tukey's test was used as a post hoc analysis. A threshold of $\mathrm{P} \leq 0.05$ was set to infer statistical significance. All statistical analyses were based on Zar (1999).

\section{Results}

\section{Reproductive performance}

The latency period was significantly higher for the CPE (18.50 hours) than for both mGnRHa treatments $\left(3.5 \mu \mathrm{g} / \mathrm{kg}^{-1}\right.$ : 15.40 hours and $5 \mu \mathrm{g} / \mathrm{kg}^{-1}$ : 15.20 hours) $(\mathrm{P}=0.03$, Table 1$)$. The percentage of spawning $(\mathrm{P}=0.26$, Table 1$)$, absolute fecundity $(\mathrm{P}=$ 0.15 , Table 1$)$ and GSI (P = 0.58, Table 1$)$ values were similar for all the CPE and mGnRHa treatments. Concerning the reproductive performance, the fertility rate for the CPE (23.6\%) was markedly higher than those for the mGnRHa treatments $\left(3.5 \mu \mathrm{g} / \mathrm{kg}^{-1}: 1.4 \%\right.$ and $\left.5 \mu \mathrm{g} / \mathrm{kg}^{-1}: 0 \%\right)(\mathrm{P}=0.012$, Table 1$)$. On the other hand, there were no significant differences in hatching rate among treatments $(\mathrm{P}=0.287$, Table 1$)$.

Table 1. Average values ( \pm Standard error) of the reproductive performance of female L. elongatus undergoing hormonal induction.

\begin{tabular}{|c|c|c|c|c|c|c|}
\hline Treatments & $\begin{array}{c}\text { Latency } \\
\text { period (h) }\end{array}$ & $\begin{array}{c}\text { Spawning rate } \\
\text { (\%) }\end{array}$ & $\begin{array}{c}\text { Absolute } \\
\text { fecundity } \\
\text { (oocyte/fish) }\end{array}$ & GSI (\%) & $\begin{array}{c}\text { Fertility rate } \\
\text { (\%) }\end{array}$ & $\begin{array}{l}\text { Hatching rate } \\
(\%)\end{array}$ \\
\hline $\mathrm{CPE}$ & $18.50 \pm 0.20^{\mathrm{a}}$ & $80.00 \pm 25.08^{\mathrm{a}}$ & $84.334 \pm 32.98^{\mathrm{a}}$ & $16.49 \pm 0.58^{\mathrm{a}}$ & $23.60 \pm 9.40^{\mathrm{a}}$ & $1.3 \pm 1.0^{\mathrm{a}}$ \\
\hline $\begin{array}{l}\text { mGnRHa } \\
\left(3.5 \mu \mathrm{g} / \mathrm{kg}^{-1}\right)\end{array}$ & $15.40 \pm 0.11^{\mathrm{b}}$ & $100.00 \pm 0.00^{\mathrm{a}}$ & $97.239 \pm 12.45^{\mathrm{a}}$ & $12.80 \pm 2.98^{\mathrm{a}}$ & $1.40 \pm 0.60^{\mathrm{b}}$ & $0.4 \pm 0.2^{\mathrm{a}}$ \\
\hline mGnRHa & $15.20 \pm 0.09^{b}$ & $100.00 \pm 0.00^{\mathrm{a}}$ & $95.338 \pm 15.23^{\mathrm{a}}$ & $11.58 \pm 3.67^{\mathrm{a}}$ & $0 \pm 0^{b}$ & $0 \pm 0^{\mathrm{a}}$ \\
\hline
\end{tabular}

$\left(5.0 \mu \mathrm{g} / \mathrm{kg}^{-1}\right)$

CPE: carp pituitary extract and mGnRHa: mammalian gonadotropin-releasing hormone analogue. Different letters indicate differences between treatments $(\mathrm{P}<0.05)$.

Volume density of oocytes from ovaries collected at the time of ovulation

The volume density of the remaining PV in the ovaries after spawning was significantly higher for the mGnRHa treatments $\left(3.5 \mu \mathrm{g} / \mathrm{kg}^{-1}: 24 \%\right.$ and $5 \mu \mathrm{g} / \mathrm{kg}^{-1}$ : 29\%) compared to the CPE treatment $(6.5 \%)(\mathrm{P}<0.0001$, Fig. 1 and 2B). The volume density of $\mathrm{CA}(\mathrm{P}=0.30$, Fig. 1), IV ( $\mathrm{P}=0.42$, Fig. 1$)$, AT $(\mathrm{P}=0.90$, Fig. 1$)$, and IT $(\mathrm{P}=0.87$, Fig. 1$)$ were similar among treatments. The volume density of CNV was higher for the CPE treatment (39\%) compared to the mGnRHa treatments $\left(3.5 \mu \mathrm{g} / \mathrm{kg}^{-1}\right.$ : $15 \%$ and $\left.5 \mu \mathrm{g} / \mathrm{kg}^{-1}: 17 \%\right)(\mathrm{P}=0.0045$, Fig. 1 and $2 \mathrm{~A})$. Similarly, the volume density of GVBD was higher for the CPE treatment (48\%) compared to the mGnRHa treatments (3.5 $\mu \mathrm{g} / \mathrm{kg}^{-1}: 14 \%$ and $\left.5 \mu \mathrm{g} / \mathrm{kg}^{-1}: 5 \%\right)$ ( $\mathrm{P}<0.0001$, Fig. 1 and 2A). On the other hand, the volume density of POF was higher for the mGnRHa treatments (3.5 $\mu \mathrm{g} / \mathrm{kg}^{-1}: 36 \%$ and $5 \mu \mathrm{g} / \mathrm{kg}^{-1}: 39 \%$ ) compared to the CPE treatment $(1 \%)(\mathrm{P}<0.0001$, Fig. 1 and $2 \mathrm{~B})$. 


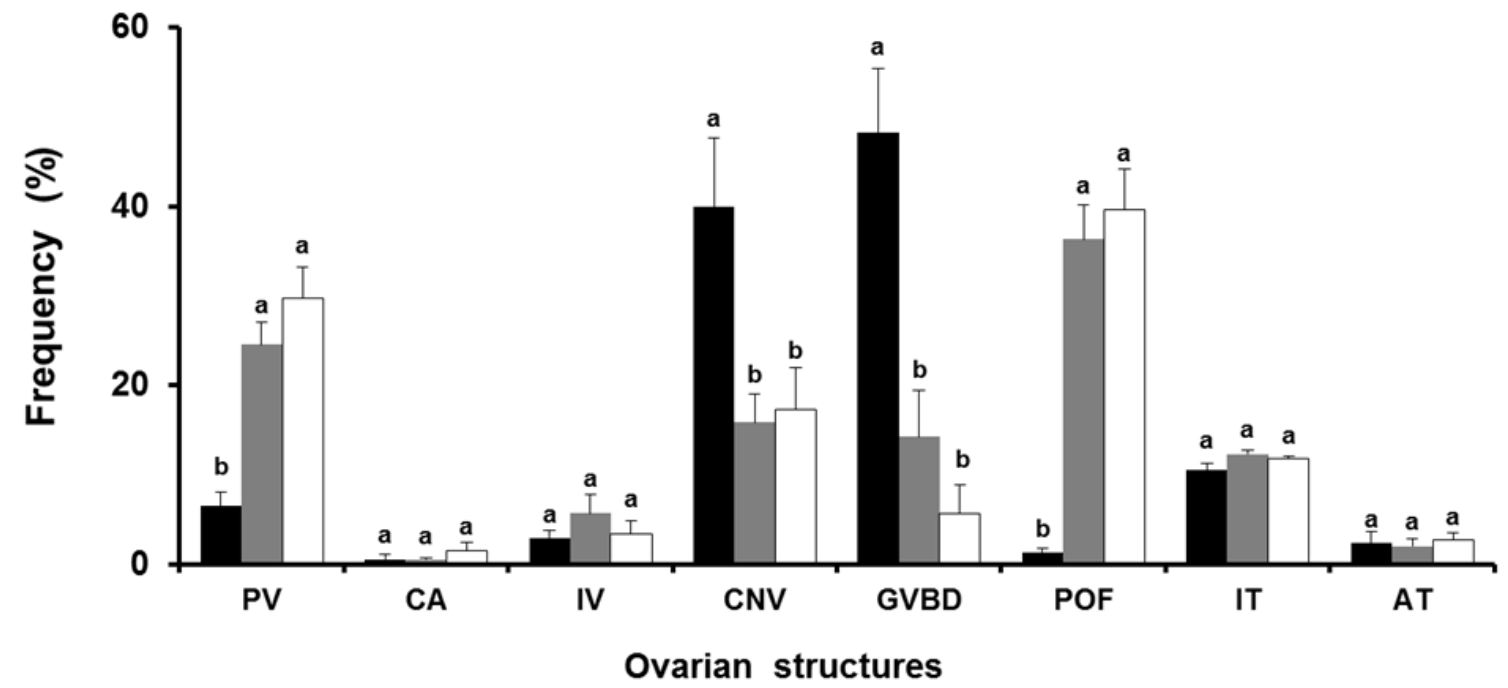

Figure 1. Percentage average values ( \pm Standard error) of the volume density of different types of ovulated ovarian oocytes collected at the time of ovulation ( $n=5$ per treatment). Different letters indicate significant difference between treatments $(\mathrm{P}<0.05)$. Oocytes: PV (previtellogenic); CA (cortical alveoli); IV (immature vitellogenic); CNV (vitellogenic oocytes with central nucleus ); MNV (mature vitellogenic oocytes with migrated nucleus); GVBD (mature vitellogenic oocyte with germinal vesicle breakdown); POF (postovulatory follicle); AT (atretic) and TI (interstitial tissue). CPE: carp pituitary extract; mGnRHa: gonadotropin-releasing hormone.
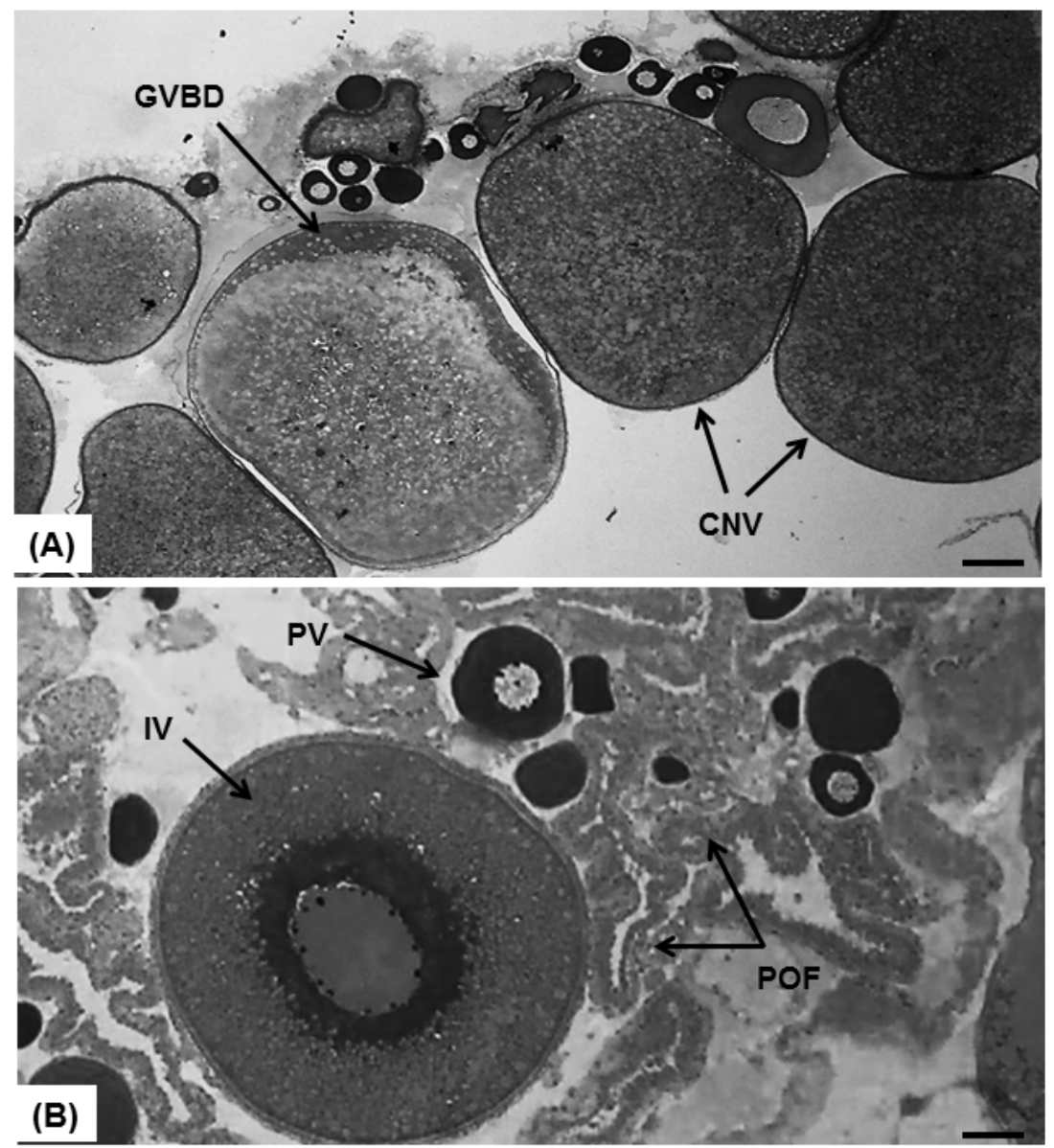

Figure 2. (A) Photomicrographs of cross sections of the ovary of $L$. elongatus females induced with CPE containing large amount of GVBD and CNV oocytes retained in post-spawning ovaries. (B) Photomicrographs of cross sections of the ovary of $L$. elongatus females induced with $\mathrm{mGnRHa}$ containing large amount of POF. 
Pereira et al. Induced spawning of Leporinus elongatus: evolution of the final maturation and ovulation.

\section{Gonadal steroids}

Plasma $\mathrm{E}_{2}$ levels were similar among treatments before hormonal induction ( $\mathrm{P}=0.30$, Table 2 ). However, during ovulation, in the $\mathrm{mGnRHa}$ treatments, levels were higher $\left(3.5 \mu \mathrm{g} / \mathrm{kg}^{-1}\right.$ : $132.06 \mathrm{pg} \mathrm{mL} \mathrm{m}^{-1}$ and $5 \mu \mathrm{gg} / \mathrm{kg}^{-1}$ : $\left.150.60 \mathrm{pg} \mathrm{mL}^{-1}\right)$ than in the CPE one $\left(74.17 \mathrm{pg} \mathrm{mL}^{-1}\right)(\mathrm{P}$ $=0.02$, Table 2). By assessing plasma levels of $\mathrm{E}_{2}$ during different sampling times within the same treatment, we could observe that in the CPE induced group there was a decrease between the first dose $\left(129.27 \mathrm{pg} \mathrm{mL}^{-1}\right)$ and ovulation (74.17 $\left.\mathrm{pg} \mathrm{mL}^{-1}\right)(\mathrm{P}=0.03$, Table 2$)$. However, there was no significant difference in $\mathrm{E}_{2}$ levels between the time of the first dose $\left(3.5 \mu \mathrm{g} / \mathrm{kg}^{-1}: 154.45 \mathrm{pg} \mathrm{mL}^{-1}\right.$ and $5 \mu \mathrm{g} / \mathrm{kg}^{-1}$ : $127.82 \mathrm{pg} \mathrm{mL}{ }^{-1}$ ) and ovulation (3.5 $\mu \mathrm{g} / \mathrm{kg}^{-1}: 132.06 \mathrm{pg} \mathrm{mL}^{-1}$ and $\left.5 \mu \mathrm{g} / \mathrm{kg}^{-1}: 150.60 \mathrm{pg} \mathrm{mL}^{-1}\right)$ in the $\mathrm{mGnRHa}$ treatments $(\mathrm{P}=0.12$, Table 2$)$.

Plasma levels of $17 \alpha-$ OHP in all CPE and mGnRHa (3.5 and $5 \mu \mathrm{g} / \mathrm{kg}^{-1}$ ) induced fish were similar during the first dose $(\mathrm{P}=0.798$, Table 2). However, during ovulation, in the $\mathrm{mGnRHa}$ treatments, levels were higher $\left(3.5 \mu \mathrm{g} / \mathrm{kg}^{-1}\right.$ : $376.04 \mathrm{ng} \mathrm{mL} \mathrm{m}^{-1}$ and $5 \mu \mathrm{g} / \mathrm{kg}^{-1}$ : $\left.401.10 \mathrm{ng} \mathrm{mL}^{-1}\right)$ than in the CPE one (229.06 $\mathrm{ng} \mathrm{mL}^{-1}$ ) $(\mathrm{P}=0.03$, Table 2$)$. By assessing plasma levels of $17 \alpha-$ OHP during different sampling times within the same treatment, we could observe that, in all treatments, levels reached a peak at the time of ovulation $(\mathrm{P}=0.0002$, Table 2).

Table 2: Average values ( \pm Standard error) of plasma levels of estradiol $\left(E_{2}\right)$ and $17 \alpha-$ hydroxyprogesterone $(17 \alpha-$ OHP) at different times during hormonal induction.

\begin{tabular}{lccc}
\hline Treatments & \multicolumn{3}{c}{ Period } \\
$\mathrm{E}_{2}$ & $\begin{array}{c}\text { First dose } \\
\left(\mathrm{pg} \mathrm{mL}^{-1}\right)\end{array}$ & $\begin{array}{c}\text { Second dose } \\
\left(\mathrm{pg} \mathrm{mL}^{-1}\right)\end{array}$ & $\begin{array}{c}\text { Ovulation } \\
\left(\mathrm{pg} \mathrm{mL}^{-1}\right)\end{array}$ \\
\hline CPE & $129,27 \pm 26.26^{\mathrm{aB}}$ & $132.15 \pm 15.67^{\mathrm{bB}}$ & $74.17 \pm 28.96^{\mathrm{aA}}$ \\
$\mathrm{mGnRHa}\left(3.5 \mu \mathrm{g} / \mathrm{kg}^{-1}\right)$ & $154.45 \pm 13.54^{\mathrm{aA}}$ & - & $132.06 \pm 15.87^{\mathrm{bA}}$ \\
$\mathrm{mGnRHa}\left(5.0 \mu \mathrm{g} / \mathrm{kg}^{-1}\right)$ & $127.82 \pm 20.91^{\mathrm{aA}}$ & - & $150.60 \pm 10.75^{\mathrm{bA}}$ \\
$17 \alpha-$ OHP & & $201.15 \pm 5.22^{\mathrm{bB}}$ & $229.87 \pm 15.82^{\mathrm{aA}}$ \\
\hline CPE & $198.08 \pm 9.87^{\mathrm{aB}}$ & - & $376.04 \pm 24.37^{\mathrm{bA}}$ \\
$\mathrm{mGnRHa}\left(3.5 \mu \mathrm{g} / \mathrm{kg}^{-1}\right)$ & $189.10 \pm 29.05^{\mathrm{aB}}$ & - & $401.10 \pm 8.45^{\mathrm{bA}}$ \\
\hline
\end{tabular}

CPE: Carp pituitary extract and mGnRHa: mammalian Gonadotropin-releasing hormone analogue. Different letters indicate differences between treatments $(\mathrm{P}<0.05)$. Different lowercase letters indicate differences between different treatments for the same periods and different capital letters indicate differences between the same treatment in different periods $(\mathrm{P}<0.05)$.

\section{Discussion}

In the present study, we demonstrated that the treatments with low mGnRHa doses were more potent for inducing final maturation and ovulation in comparison with the conventional CPE protocol, as evidenced by the statistically higher values of GVBD and POF in post-spawning ovaries, as well as the higher gonadal steroid levels (at the time of ovulation); however, none of the treatments provided viable embryos.

Although the use of conventional doses of CPEs has already been shown to provide $L$. elongatus ovulation and viable embryos (Sato et al., 2000), the low embryo viability obtained in all treatments in the present study (compared to Sato's study) may be related to the use of different conditions and broodstock in each experiment, but mainly to the use of wild breeders herein. In this concern, it is known that the effects of broodfish on gamete quality remain poorly documented and there is a complete lack of information on the effect of the domestication of wild breeders on their reproductive performance (Bobe and Labbé, 2010). It is also known that environmental control of gamete quality is far from being fully understood, especially the effect of external factors and broodstock management conditions on gamete quality (Bobe and Labbé, 2010). Moreover, we must emphasize that, in the study published by Sato et al. (2000), a large variation in the proportion of eggs retained by females and a relatively low rate of ovulation was reported, which can easily be replicated for different studies (Hainfellner et al., 2012a; Criscuolo-Urbinati et al., 2012; Pereira et al., 2017), using different broodstock, maintained under different conditions and performed in different years (with different climate characteristics).

The consistency in the results obtained using $\mathrm{CPE}$ and especially mGnRH in South American migratory fish is very far from being a reality. Induced ovulation with ovaprim (single dose: $10 \mu \mathrm{g}$ Salmon Gonadotropin Releasing hormone analog (sGnRHa) $\mathrm{kg}^{-1}$ $+5 \mathrm{mg}$ domperidone $\mathrm{kg}^{-1}$ ) has been very successful in Colossoma macropomum, but provided low quality embryos when compared to CPE (Acuña and Rangel, 2009). In a congener species, Leporinus macrocephalus, low doses of mGnRHa ( $7 \mu \mathrm{g} \mathrm{mGnRH}$ kg- $1+10 \mathrm{mg} \mathrm{kg}-$ 1 metoclopramide) provoked ovulation, but not viable embryos (Pereira et al., 2017). The induced ovulation failed in Rhamdia quelen (two doses: $2 \mu \mathrm{g}$ mGnRHa kg ${ }^{1}+1 \mathrm{mg}$ metoclopramide $\mathrm{kg}^{-1}$ and $20 \mu \mathrm{g} \mathrm{mGnRHa} \mathrm{kg}$ $+10 \mathrm{mg}$ metoclopramide $\mathrm{kg}^{-1}$ metoclopramide) (Carneiro and Mikos, 2008). When applied to Piaractus mesopotamicus, Brycon orbygnianus and Prochilodus lineatus, busserelin acetate led to ovulation, but no viable embryos were obtained after fertilization (Paulino et al., 2011). In addition, different from most South American rheophilic species, viable embryos and successful ovulation can be unusually obtained with very low doses of CPE $\left(0.5 \mathrm{mg} \mathrm{kg}^{-1}\right.$ (with successive doses every six hours, if necessary)) in Schizodon 
fasciatus (Lopes and Leal, 2010). Taken together, these findings indicate that $L$. elongatus, as well as other South American migratory species, do not respond properly (due to completely unknown reasons) to hormonal induction, especially with GnRH, which provides inconstant and very heterogeneous results of difficult reproducibility, especially if we consider that the doses applied in this study (3.5 or $5.0 \mu \mathrm{g} \mathrm{mGnRH}$ $\mathrm{kg}^{-1}+10 \mathrm{mg} \mathrm{kg}^{-1}$ metoclopramide) and for the congener L. macrocephalus $\left(7 \mu \mathrm{g} \mathrm{mGnRH} \mathrm{kg}{ }^{-1}+10 \mathrm{mg} \mathrm{kg}^{-1}\right.$ metoclopramide) which did not provide viable embryos either (Pereira et al., 2017) were much lower than the GnRHa-implant doses reported as a cause for overstimulation in other fish species (50-100 kg $\mathrm{kg}^{-1}$ (Mañanos et al., 2002; Rosenfeld et al., 2012).

According to those authors, the excessive secretion level of $\mathrm{LH}$ is one of the factors that may potentially affect the quality of eggs, promoting an overstimulation. In the present study, we did not evaluate LH levels, but considering the gonadal steroid levels evaluated, we emphasize that the CPE treatment was the only one to present a survival of the embryos $(23.60 \pm 9.40 \%) 5$ hours after fertilization and, coincidently, that treatment was the only one to present a reduction of $E_{2}$ at the time of ovulation, which remained similar over time for the mGNRHa treatments. In this concern, future approaches that correlate maternal plasma $E_{2}$ levels with embryonic survival rates would be necessary to evaluate a possible maternal $\mathrm{E}_{2}$ transfer to eggs which may cause toxicity to them. It has already been demonstrated that unbalanced maternal plasma reproductive hormones are transferred to eggs (Hwang et al., 1992; Mylonas et al., 1994) and are potential causes for embryo mortality in fish. There are also reports of higher $E_{2}$ and $17 \alpha, 20 \beta$-Dihydroxy-4pregnen-3-one $(17 \alpha, 20 \beta$-DHP) levels in non-viable eggs in relation to viable eggs (Feist et al., 1990). Furthermore, we observed excessive levels of gonadal steroids, concerning 170HP, in all treatments at the time of ovulation, when compared to the levels at the first (or single) dose, which may have been the cause for an eventual toxicity and or overstimulation, since the parameters of water used in this experiment were adequate and neither explain the embryo mortality nor the the differential fertility rates found for the three treatments used. Although expected, since 17-OHP is the precursor of 17a, 20b-DHP named "maturation inducing substance”' (MIS), which promotes germinal vesicle breakdown and the ovulation in teleosts (Lubzens et al., 2010; Ogiwara et al., 2013; Hagiwara et al., 2014), plasma concentrations of 17-OHP for the mGNRHa treatments were higher than those for the CPE treatment, at the time of ovulation.

In conclusion, the use of $\mathrm{mGnRHa}$ associated with metoclopramide was more potent for inducing the L. elongatus ovulatory process when compared to CPE, as it significantly increased the FPO volume density and gonadal steroid levels at the time of ovulation. However, the results obtained here reinforced the existing hypothesis of an ovarian hyperstimulation with consequent egg toxicity due to the hormonal treatment in this rheophilic species and other South American ones, that must be addressed in futures studies. Recent reports on embryonic mortality obtained in spawning induced South American migratory species (Acuña and Rangel, 2009; Carneiro and Mikos, 2008; Paulino et al., 2011; Pereira et al., 2017), coupled with the need for hormone-inducing such species in order to obtain embryos, point out to an immediate need for speciesspecific studies (probably in vitro) in order to confirm which substances used in hormone therapies (and their derivatives), as well as which levels are indeed toxic to the eggs. This aspect needs to be addressed for the development of aquaculture in countries which depend on these species, since rheophilic fish are known to be among the most important fish for commercial purposes in South American countries (MPA 2013; FAO 2014) and the constant and predictable supply of fingerlings is imperative for the consolidation of the use of any species for aquacultural purposes.

\section{Acknowledgements}

We thank Duke Energy for the use of their facilities (Salto-Grande, São Paulo-Brazil) and for the generous donation of the fish used in this study.

\section{References}

Acuña JJA, Rangel JLH. 2009. Effects of Hypophysial Extract of Common Carp and the Analog of the GnRH on the final maturation oocyte and the spawning of cachama negra (Colossoma macropomum). Rev Cient FCV-LUZ, 19:486-494.

Bobe J, Labbé C. 2010. Egg and sperm quality in fish. Gen Comp Endocrinol, 165:535-548.

Britto SGC, Carvalho ED. 2013. Reproductive migration of fish and movement in a series of reservoirs in the Upper Parana River basin, Brazil. Fish Manag Ecol, 20:426-433.

Brown J, Walker SE, Steinmain K. 2004. Endocrine manual for reproductive assessment of domestic and non-domestic species, Conservation and Research Center, Smithsonian's National Zoological Park, Front Royal, Virginia, EUA.

Caneppele D, Sanches EA, Romagosa E. 2015. Sperm production of Steidachneridion parahybae (Steindachner 1877) and the effect of hormonal induction throughout one reproductive cycle. J Appl Ichthyol, 31:54-61.

Carneiro PCF, Mikos JD. 2008. Gonadotrofina coriônica humana e hormônio liberador de gonadotrofina como indutores da reprodução do jundiá. Acta Sci Anim Sci, 30:345-350.

Criscuolo-Urbinati E, Kuradomi RY, Urbinati EC, Batlouni SR. 2012. The administration of exogenous prostaglandin may improve ovulation in pacu (Piaractus mesopotamicus). Theriogenology, 78: 2087-2094.

De Souza TG, Hainfellner P, Kuradomi RY, Munõz ME, Honji RM, Moreira RG, Batlouni SR. 2015. Inappropriate management conditions, especially for the regressed class, are related to sperm quality in Prochilodus lineatus. Theriogenology 8:797-807.

Duke Energy International, Geração Paranapanema 
S/A. 2003. Peixes do rio Paranapanema. São Paulo: Horizonte Geográfico, 112 p.

Food and Agriculture Organization of the United Nations (FAO). 2014. The state of world fisheries and aquaculture, Rome: FAO. Available on: www.fao.org. Accessed on: January 1, 2017.

Feist G, Schreck CB, Fitzpatrick MS, Redding JM. 1990. Sex steroid profiles of coho salmon (Oncorhynchus kisutch) during early development and sexual differentiation. Gen Comp Endocrinol, 80:299-313.

Giamas MTD, Vermulm-JR H. 2004. Levantamento da pesca profissional continental no Estado de São Paulo em 2001. Dados preliminares: Bacia do Rio Paranapanema, Paraná e Grande. Série Relatórios Técnicos, São Paulo, 8:1-11.

Godinho HP. 2007. Estratégias reprodutivas de peixes aplicadas à aquicultura: bases para o desenvolvimento de tecnologias de produção. Rev Bras Reprod Anim, 31:351-360.

Hagiwara A, Ogiwara K, Katsu Y, Takahashi T. 2014. Luteinizing Hormone-induced expression of Ptger4b, a prostaglandin $\mathrm{E}_{2}$ receptor indispensable for ovulation of the medaka Oryzias latipes, is regulated by a genomic mechanism involving nuclear progestin receptor. Biol Reprod, 90, 1-14.

Hainfellner P, Munõz ME, Souza TG, Freitas GA, Batlouni SR. 2012a. Spawning failure in Brycon amazonicus may be associated with ovulation and not with final oocyte maturation. Arq Bras Med Vet Zoo, 64:515-517.

Hainfellner P, Souza TG, Moreira RG, Nakaghi LSO, Batlouni SR. 2012b. Low estradiol levels, delayed vitellogenesis and reduced amounts of yolk are dysfunctions associated with the formation of low quality oocytes in Prochilodus lineatus (Teleostei: Characiformes). Neotrop Ichthyol, 10:601-612.

Hwang P, Wu S, Lin J, Wu L. 1992. Cortisol content of eggs and larvae of teleosts. Gen Comp Endocrinol, 86:189-196.

Instituto Brasileiro de Geografia e Estatística (IBGE). 2014. Produção da Pecuária Municipal. IBGE, Ministério do Planejamento, Orçamento e Gestão, 41:108p.

Ittzés I, Szabó T, Kronbauer EK, Urbanyi B. 2015. Ovulation induction in jundia (Rhamdia quelen, Heptapteridae) using carp pituitary extract or salmon GnRH analogue combined with dopamine receptor antagonists. Aquac Res, 46:2924-2928.

Lopes JP, Leal ALG. 2010. Desova induzida em Piaude-vara Schizodon fasciatus spix \& agassiz, 1829 para propagação artificial. Rev Bras Eng Pesca, 5:XIV-XX. Lubzens E, Young G, Bobe J, Cerdà J. 2010. Oogenesis in teleosts: How fish eggs are formed. Gen Comp Endocrinol, 165:367-389.

Makrakis S, Makrakis MC, Wagner RL, Dias JHP, Gomes LC. 2007. Utilization of the fish ladder at the Engenheiro Sergio Motta Dam, Brazil, by long distance migrating potamodromous species. Neotrop Ichthyol, 5:197-204.

Mañanos E, Carrillo M, Sorbera LS, Mylonas CC,
Asturiano JF, Bayarri MJ, Zohar Y, Zanuy S. 2002. Luteinizing hormone and sexual steroid plasma levels after treatment of European sea bass with sustainedrelease delivery systems for gonadotropin-releasing hormone analogue. J Fish Biol, 60:328-339.

Ministério da pesca e Aquicultura (MPA). 2013. Boletim estatístico da pesca e aquicultura. Brasília: República Federativa do Brasil. Aviable on: www.mpa.gov.br. Accessed on: September 9, 2016.

Mylonas CC, Sullivan CV, Hinshaw JM. 1994. Thyroid hormones in brown trout (Salmo trutta) reproduction and early development. Fish Physiol Biochem, 13:485-493.

Mylonas CC, Fostier A, Zanuy S. 2010. Broodstock management and hormonal manipulations of fish reproduction. Gen Comp Endocrinol, 165:516-534.

Ogiwara K, Fujimori C, Rajapakse S, Takahashi T. 2013. Characterization of Luteinizing Hormone and Luteinizing Hormone Receptor and Their Indispensable Role in the Ovulatory Process of the Medaka. Plos one, 8:e54482.

Paulino MS, Milliorini AB, Murgas LDS, Lima FSM, Felizardo VO. 2011. Desempenho reprodutivo do pacu, piracanjuba e curimba induzidos com extrato de buserelina. Bol Inst Pesca, 37:39-45.

Pereira TSB, Boscolo CNP, Moreira RG, Batlouni SR. 2017. The use of $\mathrm{mGnRHa}$ provokes ovulation but not viable embryos in Leporinus macrocephalus. Aquacult Int, 25:515-529

Petrere M Jr, Agostinho AA, Okada EK, Julio Jr HF. 2002. Review of the fisheries in the Brazilian portion of the Paraná/Pantanal basin. In: Cowx, I.G. (ed.), Management and ecology of lake and reservoir fisheries. Oxford, Fishing News Books, 123-143.

Rosenfeld H, Mylonas CC, Bridges CR, Heinisch G, Corriero A, Vassallo-Aguis R, Medina A, Belmonte A, Garcia A, De la Gándara F, Fauvel C, De Metrio G, Meiri-Ashkenazi I, Gordin H, Zohar Y. 2012. GnRHa-mediated stimulation of the reproductive endocrine axis in captive Atlantic bluefin tuna, Thunnus thynnus. Gen Comp Endocrinol, 175:55-64.

Sato Y, Fenerich-Verani N, Verani JR, Vieira LJS, Godinho HP. 2000. Induced reproductive responses of the neotropical anostomids fish Leporinus elongatus Val. under captive breeding. Aquacult Res, 31:189-193.

Schorer M, Moreira RG, Batlouni SR. 2016. Selection of pacu females to hormonal induction: effect of age and of evaluation methods. Bol Inst Pesca, 42:901-913.

Streit-JR DP, Sirol RN, Ribeiro RP, Moraes GV, Vargas LDM, Watanabe AL. 2008. Qualitative parameters of the piapara semen (Leporinus elongatus Valenciennes, 1850). Braz J Biol, 68:373-377.

Viveiros ATM, Goncalves AC, Chiacchio IM, Nascimento AF, Romagosa E, Leal MM. 2015. Gamete quality of streaked prochilod Prochilodus lineatus (Characiformes) after $\mathrm{GnRHa}$ and dopamine antagonist treatment. Zygote, 23:212-221.

Zar JH. 1999. Biostatistical Analysis, 4th ed. Upper Saddle River, NJ: Prentice Hall. 